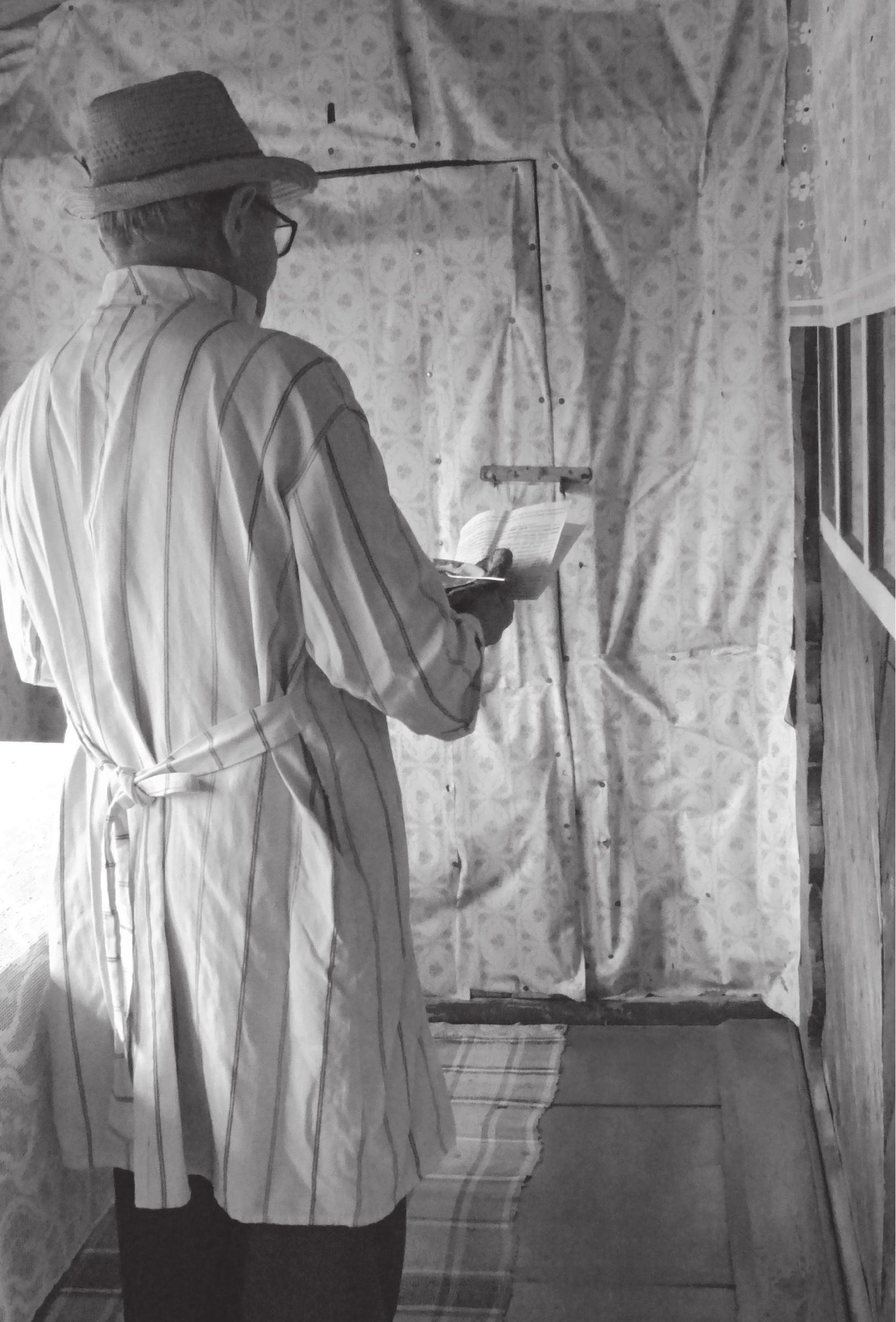




\section{Kaama-taguste udmurtide sügispalvus: rituaali etnograafiline kirjeldus välitööde põhjal'}

\section{Eva Toulouze}

\section{Sissejuhatus}

Udmurtide põhiasuala jääb Vjatka ja Kaama jõe vahele. Nad jagunevad mitmesse etnograafilisesse rühma, igal oma eristavad kultuurilised jooned. Siinkohal keskendun idapoolsemale rühmale, mis Udmurtiast vaadates asub Kaama jõe taga, Baškortostani põhjaosas ning sellega piirneva Permi krai Kujeda rajoonis. See grupp tekkis udmurtide tuumikalal elanud lõunaudmurtide migratsiooni tagajärjel. 17. sajandist alates põgenesid mitme udmurdi küla elanikud vägivaldse ristiusustamise tõttu islamiusuliste tatarlaste ja baškiiridega asustatud aladele, kus nad said edasi elada oma reeglite ja usukommete järgi (Minniyakhmetova 1995: 332; Sadikov 2008: 7). Nõnda eksisteerib tänapäevalgi nendel aladel väike udmurtide kogukond (rahvaloenduste järgi umbes 20000 inimest), keda iseloomustab tugev udmurdi identiteet, vähene kokkupuude venelastega, tugev keeleline ja kultuuriline tataribaškiiri mõju ning tänini säilinud omausk. Sajandite jooksul on mõned külad küll läinud üle "tatari usule“ (islamile) ja tatari keelele, enamik on aga siiani alal hoidnud udmurdi keele ja usukombestiku, mis ülejäänud udmurtide seas on säilinud vaid marginaalselt, õigeusu varjus ning peamiselt sünkretismi vormis.

Kaama-taguste udmurtide erandlikkus on teadlasi ammu huvitanud. 19. sajandil ja 20. sajandi algul vaatlesid ja kirjeldasid uurijad enamasti nende suuremaid kogukondlikke rituaale (Heikel 1884; Wichmann 1893; Holmberg 1914; Munkácsi 1952; Wichmann, Wichmann 1987; vt ka Sadikov, Minniyakhmetova 2012). Ateistlikult meelestatud nõukogude perioodi teadlased Kaama-taguste udmurtide usupraktikaid ei uurinud, kuid Baškiirias püsisid need üsnagi visalt. Mõned rituaalid

[1] Artikli kirjutamist toetas Eesti Teadusagentuur (PUT 590 „Tänapäevane soome-ugri animism: funktsioonid ja sotsiaalne kontekst“", 2015-2018).

Farhulla Garifanov palvetab oma verandal. 
küll kadusid tasapisi ja nooremad põlvkonnad ei jälginud vanu kombeid sama agaralt kui vanemad inimesed, kuid paljusid palvuseid peeti siiski edasi. Nõukogude aja lõpul algas ühelt poolt usupraktikate võimas taaselustamine (Toulouze 2016; Toulouze et al. 2018), teisalt hakkasid teadlased seda teemat uuesti käsitlema. Nad keskendusid nõukogude-eelse traditsiooni uurimisele kui kõige omapärasemale, ehtsamale ja huvipakkuvamale teemale. Kui esimesed uurijad tulid enamasti väljastpoolt Venemaad, siis 20. sajandi lõpu teadlased pärinevad uuritavast kogukonnast endast ehk teisisõnu on Baškiiria udmurdid (Tatjana Minnijahmetova, Ranus Sadikov).

See artikkel keskendub ühele Kaama-taguste udmurtide usurituaalile, nimelt sügispalvusele (сӥзьыл куриськон). Sedalaadi intiimsemad rituaalid on kas isiklikku laadi (surm, sünd, sõjaväkke minek, pulmad) või määratud rituaalsest kalendrist. Viimaste hulka kuulub ka sügispalvus. Suuremal osal neist rituaalidest on üldine eesmärk: kindlustada kogukonna või mõne selle alaosa heaolu ja turvalisus. Sügispalvusel ei väljendata erilist tänulikkust saagi eest, nagu võiks eeldada rituaali ajastusest. Samas on kindlasti tegu rituaalse kalendri üleminekuga ühest perioodist teise (suveperioodist talveperioodi) (Minnijahmetova 2000: 69-71). Udmurdi kalendris esineb suhteliselt palju kindlal ajal peetavaid rituaale, mille eesmärk on kindlustada grupi heaolu. Sügispalvust viib läbi lähisugulaste patrilineaarne grupp.

Ma olen Kaama-taguste udmurtide juures välitöid teinud alates 2013. aastast, keskeltläbi kaks korda aastas, alati koos kaaslastega - kohaliku religiooniuurija Ranus Sadikoviga, kes on sellest kogukonnast pärit, ning visuaalantropoloog Liivo Niglasega, kelle ülesandeks on uuritavaid rituaale filmida. Lisandunud on veel religiooniuurija Laur Vallikivi ja folklorist Nikolai Anisimov. Viimane on ka ise udmurt, kuid teisest etnograafilisest grupist. Oktoobris 2017 koosnes meie uurimisgrupp neljast inimesest: mina ise, Liivo Niglas, Nikolai Anisimov ja udmurdi filmitegija Denis Kornilov. Nendest kaks - Liivo Niglas ja mina - ei valda udmurdi keelt ja kasutavad nõnda välitöödel pigem vene keelt. Vene keelt oskavad muidugi kõik elanikud kasvõi juba kooli tõttu, kuid nende oskused on väga varieeruvad ja paljud vanemad külanaised kasutavad vene keelt vähe ega tunne end selles keeles suheldes vabalt (Toulouze 2014; 2017). Mehed ja nooremad inimesed valdavad vene keelt tavaliselt vabalt. Nikolai Anisimov on lõunaudmurdi teadlane, kes tunneb Kaama-taguseid udmurte ja nende murret hästi. Denis Kornilov on Tatarstanist pärit udmurdi doktorant, kes viibis 2017. aastal Kaama-taguste udmurtide juures esimest korda. Me moodustasime kaks kaheliikmelist meeskonda (Toulouze-Kornilov, Anisimov-Niglas), kummagi koosseisus üks filmitegija ja üks udmurdi keele oskaja. See võimaldas tutvuda eri paigus samaaegselt toimuvate rituaalidega ja neid ka filmida.

Välitöid finantseeris Institut Universitaire de France, mille liikmeks olen ma saanud just Kaama-taguste udmurtide usupraktikate uurimise projektiga, millesse olen kaasanud nii Kaama-taguste udmurtide seast võrsunud teadlasi kui ka muud päritolu uurijaid - Udmurdimaa udmurte, eestlasi, ungarlasi ja prantslasi. ${ }^{2}$

[2] See projekt kestab 2018-2022. Liivo Niglase osalust toetas Eesti Teadusagentuur (PUT 590). 
Järgnevalt annan ülevaate Kaama-taguste udmurtide sügispalvustest, nagu need tänapäeval toimuvad kolmes peres kolmes Baškortostani külas. Kuna kogu kogetud reaalsust pole võimalik sõnadesse panna, toon siin välja just need detailid, mis tundusid mulle eelmiste kogemuste põhjal tähenduslikud.

\section{Sügisrituaalid}

Sügisrituaalid on väiksema ringi üritused. Neid on peamiselt kaht tüüpi: sügispalvus (сӥзьыл куриськон) ja sügisene mälestamisrituaal (сӥзыыл кисьтон). Каатаtagustel udmurtidel on sügispalvus oktoobri algupoolel. Palvus peab olema peetud enne 14. oktoobrit, et see ei langeks kokku surnute auks peetavate tseremooniatega. Iga pere otsustab ise vastavalt oma võimalustele, millal palvust pidada. Teine sügisrituaal, sügisene mälestamine toimub tavaliselt novembri alguses. Meie otsustasime 2017. aasta oktoobri alguses tutvuda lähemalt just sügispalvusega. Siinkohal annan aru nendest tseremooniatest, mida mina vaatlesin koos Denis Korniloviga ja mis on ka videosse salvestatud.

Käisime sügispalvust vaatlemas Baškortostani Tatõšlõ rajoonis mitmes külas, kus me oleme alates 2013. aastast välitöid teinud ja kus meid nüüdseks päris hästi tuntakse. Tatõšlõ rajoonis asuvad kompaktselt koos 19 udmurdi küla, mis jagunevad kaheks religioosseks grupiks, mille traditsioonid pisut erinevad. Gruppidevaheline piir on jõeke nimega Jug. Lähtudes külast, kus kumbki grupp peab oma ühiseid palvuseid, nimetame neid Vilgurti ja Algaa grupiks. Me otsustasime külastada mõlema grupi esindajaid.

Sügisrituaalidest on seni väga vähe kirjutatud. Neid on pigem mainitud, kui analüüsitud. Udmurdi religiooni teenekas uurija Vladimir Vladõkin oma raamatus ${ }^{3}$ lihtsalt mainib neid ilma pikema kommentaarita (1994: 226, 247). Minnijahmetova (2003) ei maini neid oma väitekirjas üldse, küll aga ühes varasemas raamatus (2000). Ranus Sadikovi doktoritöös leiame mõned viited: ta märgib, et sügispalvus (сӥзьыл куриськон) on analoogne rituaal kevadisele suurepäeva riitusele, mis vastab kristlikele ülestõusmispühadele (Sadikov 2011: 209). Sadikovi järgi on see sügavalt perekondlik ning selles saavad osaleda ainult pereliikmed (samas: 307-308). Natuke täpsemalt kirjeldab ta kommet Bui udmurtide 4 juures, kus iga peremees palvetas oma õues ja külalisi kutsuti ka teistest küladest (samas: 327). Holmbergi andmetel ohverdasid Bui udmurdid maa jumalusele Mu kõltšinile (Му кылчын) musta härja (vt samas: 307). Selle kombe kohta pole tänapäeval aga midagi teada.

Esialgse uurimise järgi saime teada, et paljudes kohtades on sügispalvus ikka alles, kuigi mitte igal pool. Näiteks kinnitas üks informant meile telefonitsi, et Jermekejevo rajoonis ei peeta seda enam üldse. Meie andmeil ei tähistata seda ka Janauli rajoonis. See-eest Tatõšlõ rajoonis on see komme veel enamasti alles. Teame, et sügispalvust peetakse ka Baltatševo rajoonis Asavka külas.

[3] Vladõkini 1994. aastal ilmunud raamat on esimene ulatuslik uurimus udmurdi religioossest maailmast ja Vladõkin on tänini selles vallas põhiline autoriteet.

[4] Bui udmurdid on üks Kaama-taguste udmurtide etnograafilisi alarühmi. Nimetatud Bui jõe järgi. 
Tänapäeval on selle rituaali vormiks, vähemalt seal, kus meie saime osaleda, kogunemine ühte majja. On mainitud, et kunagi (aeg jäi määratlemata) käidi ka sugulaste majades nagu Varkled-Bodjas (Tatarstanis) suure päeva rituaali puhul (vt Toulouze, Anisimov 2018), kuid rituaalis osalejad teavad seda ainult kuulduste põhjal ja mitte enda kogemusest. Kogunemist ühes majas kui rituaali vormi mainib ka Minnijahmetova (1996).

\section{Külastatud pered}

Käisime rituaali vaatamas kolmes peres.

\section{Garifanovite pere}

Esimene pere, kus käisid Denis Kornilov (kaameraga) ja mina, elab Nižnebaltatševo külas. Mina külastasin seda majapidamist teist korda. Pereisa, 71-aastane Garifulla Garifanov, ${ }^{5}$ keda kõik nimetavad Farhulla agai'ks, ${ }^{6}$ on mulle tuttav alates 2013. aastast. Tema on see mees, kes korraldab nii oma küla kui ka külade ühiseid rituaale Algaa grupis. Meie suhted on aastatega muutunud üha soojemaks. 2016. aasta suvel kutsus ta mind ja mu uurimisgruppi enda poole ning me saime tuttavaks ka tema abikaasa Hafizaga ning ühega nende poegadest. Poeg elab Permi krai Tšernuška linnas, kus leidub palju venestuvaid udmurte.

\section{Nurtdinovite pere}

Teine pere asub Urazgildõ külas (udmurdi keeles Vukogurt), mis kuulub Vilgurti küladegruppi. Olin perenaise Madinaga põgusalt tuttav, sest ta oli osalenud naiste laulukogunemistel Tartu ülikooli doktorandi Anna Baidullina juures, kes elab samas külas. Peremehe Saljahudtin Nurtdinoviga polnud ma aga üldse tuttav. Siiski olid nad hea meelega nõus meid vastu võtma. Nii Garifanovite kui Nurtdinovite pere isa-ema on vanema põlvkonna esindajad, umbes 70-aastased pensionärid.

\section{Samigulovite pere}

Kolmas pere oli see, kelle juures me elasime. Irina ja Mars Samigulov elavad Novõje Tatõšlõ külas (udmurdi keeles Vilgurt) oma noorima, seitsmeaastase pojaga. Teised lapsed on suured ja elavad eraldi (Permis, Iževskis, Ufas). Naine, kes on ka luuletaja, on olnud ajakirjanik kohalikus udmurdikeelses lehes ja juhib nüüd udmurdi kultuurikeskust ning korraldab hulgaliselt üritusi. Mees töötab rajoonikeskuses sõiduõpetajana. Samigulovite peremees-perenaine on nooremad, umbes 45-aastased ja neil pole oma külas lähisugulasi. Nad peavad küll sügispalvust, aga alati kiirustades, viimasel hetkel, sest mõlemad töötavad ja on väga hõivatud.

Kõikides külastatud peredes on suhtluskeel udmurdi keel. Aga kõik räägivad ka väga head vene keelt, mis vanemate inimeste puhul näitab, et enne pensionile minekut on neil olnud teatud ühiskondlik positsioon.

[5] Siin ja allpool võib onomastikas ära tunda turgi mõju.

[6] Agai-udmurdikeelne sugulustermin, mis tähistab vanemat venda või onu. Seda kasutatakse austava tiitlina, pöördudes vanema meesterahva poole. 


\section{Millest koosneb sügispalvus tänapäeval?}

Selle põhjal, mida sain vaadelda, võib sügispalvuses eristada kolme etappi: kogunemine, palvetamine ja ühissöömine.

Kogunemine. Sügispalvus toimub inimeste kodus. Sinna kogunevad lähisugulased, kes palvetavad, söövad koos pühitsetud putru, pidulikke toite ja suupisteid ning ajavad juttu. Üldiselt püüavad kõik kohal olla. See on üks sugulussidemeid tugevdavatest rituaalidest.

Palvetamine. Peremees palvetab valju häälega, käes kauss perenaise valmistatud pudruga. See toimub tavaliselt toast väljas, õues või esikus.

Ühissöömine. Kõik istuvad laua ümber, nii naistel kui meestel on pea kaetud, maitsevad pühitsetud putru, söövad igasuguseid häid asju ja ajavad rahulikult juttu.

Vaatleme nüüd iga etappi lähemalt.

\section{Kogunemine}

Sügispalvus on perekondlik üritus, kuigi ületab perekonna piire kitsamas mõttes. Üldjuhul on kutsutud suguvõsa lähim ring: vennad-õed, nende abikaasad ja lapsed koos peredega. See on üritus, kuhu püütakse kohale tulla. Aga kui palvus langeb argipäevale, siis ei saa kaugemal töötavad lapsed osaleda. Nõnda juhtuski Garifanovite ja Nurtdinovite juures, kus oli kohal vanem põlvkond ning poegade naised ja nende lapsed. Pojad ise olid tööl, välja arvatud need, kes elasid samas külas.

Vaadeldud palvused erinesid veidi üksteisest, kuid kaks esimest sarnanesid teineteisega rohkem. Koos oli üsna suur hulk erinevatesse põlvkondadesse kuuluvaid külalisi. Nurtdinovite juures olid ka väikesed lapselapsed. Lauad olid rikkalikult kaetud, üritused toimusid päevasel ajal. Nii Garifanovite kui Nurtdinovite juures kandsid perenaised rahvariideid ja olid ilusasti ehitud. Köögis oli perenaistel valmimas puder. Puder on Kaama-taguste udmurtide juures, kelle ühiskond on agraarne, peamine rituaalne toit. Pudrukeetmine ongi kogukondlike palvuste keskne sakraalne tegevus. Putru tehakse mitmesugusest viljast, välja arvatud tatar ja hernes. Tatart välditakse seetõttu, et selle värv on tume, palvetatakse aga valge jumala poole. Herneterad meenutavad aga rahet ning kardetakse, et nende kasutamine võib rahet esile kutsuda. Sageli keedetakse puder mitmest viljast, ka riisist (nagu käesoleval juhul) või mannast, kui on väga kiire. Sakraalne puder keedetakse lihapuljongis. Vahel pannakse ka liha pudru sisse, vahel mitte. Perenaised täitsid sel korral plekk-kausi lihata pudruga, mis oli keedetud kus hane-, kus veisepuljongis. Pudru keskele tegid nad augu, mis täideti Garifanovite juures sulatatud või ja Nurtdinovite juures õli ja või seguga. Nii tekkis ilus päikest meenutav pilt kollase ringiga keskel.

Samigulovite peres õiget kogunemist ei toimunudki. Võib arvata, et eelmistel aastatel oli see rituaal pidulikum, sest tegu on neljalapselise perega, kuid koju on alles jäänud vaid noorim, seitsmeaastane poeg Emil. Vanem põlvkond seekord puudus. Marsi ema ja Irina isa, kes tavaliselt elavad koos perekonnaga, olid para- 


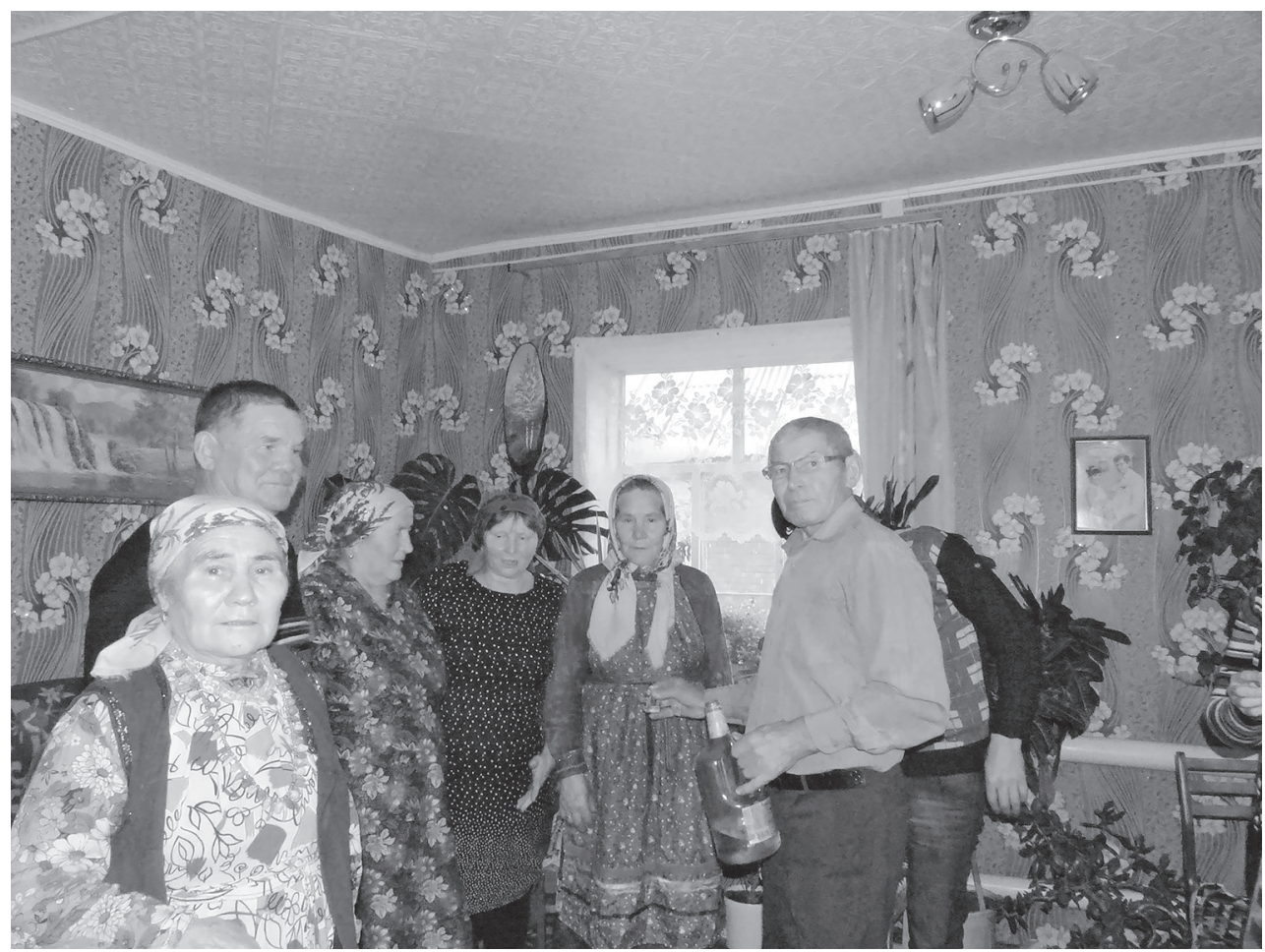

Garifanovite majapidamine. Kogunenud perekond, esiplaanil perenaine Hafiza.

Foto: Eva Toulouze 2017

jasti külastamas sõpru-sugulasi teistes külades. Perenaine, kes töötab täiskohaga, valmistas rituaalse pudru ja mees tuli sel õhtul varem koju, et saaks korralikult palvust pidada.

\section{Palvetamine}

Palvetamine on meeste ülesanne ja kõikides peredes tegid peremehed seda ise. Oma riietusse suhtusid nad aga erinevalt.

Farhulla agai pani palvetamiseks selga ohvripapi rüü. Traditsiooniliselt kandis udmurdi ohvripapp pikka rüüd nimega šortderem. See oli õmmeldud heledast mustade triipudega kodukootud kangast. Kuna aga on kombeks, et inimene maetakse šortderem' is ning vajalikku kangast enam käsitsi ei koota, siis on rüüsid vähe järele jäänud. Tatõšlõ rajoonis olen ma näinud ainult kaht ohvripappi, kes vana kodukootud šortderem'i kasutavad. Teised on sakraalse riietumise küsimuse lahendanud erinevalt. Vahel asendatakse šortderem heleda töökitliga. Farhulla külas lasti rüüd õmmelda vana kangast meenutavast poeriidest, mille triibud on aga tunduvalt laiemad kui originaalil. Selliseid rüüsid, umbes 10-15 tükki, tellis arvatavasti 2013. 
aasta sügisel kooperatiiv Rassvet, ${ }^{7}$ mille pearaamatupidaja on peamine ohvripapp Jevgeni Adullin. Oma küla palvustel ja külade ühispalvusel Farhulla seda selga ei pane, sest tema seal ei palveta. Kuid sügispalvusel oli tal teine roll. Kostüümi juurde käib ka vöö, Kaama-tagustel udmurtidel õigemini pikk tikitud rätik, mis seotakse ümber vöökoha.

Ohvripapil või palvetaval mehel peab pea olema kaetud (välja arvatud väga konkreetsetel puhkudel, näiteks kui palvetatakse, tänades jumalat rahaliste ohverduste eest). Peakate võiks olla hele nagu palvetajate riietus üldiselt. Sageli kaetakse pea mütsi või soniga, Fahulla agai kattis pea kübaraga.

Jalatsite kohta pole palju öelda, need ei erine argistest. Siiski on ühe informandi teatel ${ }^{8}$ soovitatav, et palvetamine toimuks otseühenduses maaga ehk hoovis ja näiteks viiskudes, et kontakt oleks nii loomulik ja vahetu kui võimalik. Tundub, et sellest reeglist eriti kinni ei peeta.

Nurtdinovite peres polnud peremehel võtta mingeid erilisi staatust näitavaid riideid. Ta sidus lihtsalt vööle vana pika ruudulise rätiku, mille kinnitas haaknõelaga. Peas oli tal tübeteika. Samigulovite peres ei pannud Mars selga midagi erilist, kattis vaid pea valge soniga.

Garifanovite juures pani perenaine Hafiza köögis pudrukausi rätiku peale ja tõi lauale. Mees võttis selle sealt koos rätikuga kätte ja läks palvetama. Ka Nurtdinovite pool tegi perenaine sedasama: ta viis pudrukausi lauale pärast seda, kui köögis olid kõik väikesed lapsed jälginud, kuidas ta kaussi täidab. Irina Samigulova andis esmalt väikesele pojale eraldi taldriku pudruga ning seejärel tõi pudrukausi lauale nagu teisedki perenaised.

Mina neid ei jälginud, ${ }^{9}$ kuid Denis Kornilov filmis palvetavaid pereisasid kõigis kolmes majapidamises. Farhulla agai võttis laualt pudrukausi koos rätikuga ning läks verandale ja luges paberilt palve. Mitte väga sujuvalt, sest ilmselt tuleb tal seda harva teha. Lõpus ta kummardus, öeldes omin', ${ }^{10}$ tuli tuppa, pani pudru lauale ning maitses seda koos sulatatud võiga, lausudes mingeid häid soove. Teised inimesed jätkasid samal ajal oma juttu. Siis proovis putru perenaine, kes samuti ütles palvesõnu, soovides kõigile tervist. Seejärel istusid kõik laua taha. Kõigil olid pead kaetud. Noorem tüdruk, kellel varem oli pea katmata, pani rätiku pähe. Sakraalsete tegevuste puhul ongi kombeks, et kõigil on pea kaetud, nii naistel kui ka meestel. Palja peaga ei ole sünnis sakraalse tegevuse juures viibida.

[7] Nõukogude ajal oli territoorium jaotatud kolhooside vahel. See jaotus kehtib endiselt, ainult kolhooside asemel on nüüd kooperatiivid. Nimed on jäänud samaks ning rahvasuus nimetatakse neid ikka kolhoosideks.

[8] Lilija Garajeva, Aribaši küla, Tatõšlõ rajoon.

[9] Kuigi palvetamine on üdini meeste asi, pole siin tegemist keeluga. Pigem minupoolse sooviga mitte segada palvetamise loomulikku keskkonda ja mitte tekitada olukorda, kus intiimset tegevust jälgib rohkem inimesi kui filmija. Pealegi oleks Farhulla jälgimiseks tulnud jätta pooleli jutt selle pere naistega. Olen siiski veendunud, et kas või viisakusest oleks mul lubatud palvet jälgida. Samas ei kaotanud ma suurt midagi, kuna on olemas videolindistus. [10] Selle aamen' it meenutava sõnaga lõpetatakse kõik udmurdi palved, pikemate palvete sees öeldakse seda õige mitu korda. Sellega kaasneb ohvripapi kummardus, põlvili palvetajate puhul nii sügav, et pea puudutab maad. See sõna esineb nii Piiblis kui ka Koraanis. Käesoleval juhul võib oletada islami mõju. 
Nurtdinovite pool pani peremees oma kätele lahtise valge rätiku ja perenaine asetas rätikule pudrukausi. Enamik külalisi polnud siis veel kohal, ainult paar noormeest, kellel pea alles katmata. See näitab, et nende jaoks polnud sündmuse sakraalne osa veel alanud. Peremees läks hoovi palvetama. Ta rääkis lühidalt, aga peast, pealtnäha improviseerides ja vaid kummardas lõpus vaevumärgatavalt. Palves oli pöördumine jumal Inmari poole, keda nimetatakse valgeks jumalaks, ning kellelt palutakse inimestele tervist, head saaki ning tervet karja. Tekst ei erinenud sisuliselt tavalisest palvest, kuid oli tunduvalt lühem. Nendes tekstides, mida meie kuulsime, polnud erilisi uuendusi. Näiteks ei palvetatud selle eest, et noored ei langeks narkomaania ohvriks, nagu mõnel pool tänapäeval tehakse. Kui peremees tuppa tagasi tuli, olid külalised juba laua taga, kõik kaetud peaga, kaasa arvatud lapsed. Kui Garifanovite pool olid naised vanamoodsates lillelistes riietes, siis siin kandsid nooremad naised märksa moodsamaid kleite. Peremees proovis esimesena putru, soovides valju häälega lastele tervist. Seejärel maitsesid putru ka kõik teised. Köögist saabunud perenaine sõi samuti putru, aga ei öelnud valjusti midagi.

Samigulovite peres tõusis pereisa lihtsalt oma kohalt ning lausus udmurdi keeles kõik soovid otse laua juures, istus siis ja maitses putru. Tema sõnavõtt meenutas pikka toosti heade soovidega. Esimesi lusikatäisid süües rääkis ta aga veel pikalt, soovides head nii oma perele kui kogu maailmale.

Kahe esimese tegevuse juures võib niisiis näha teatavat rituaalset mustrit. Kahes majapidamises, kus pererahvas kuulub vanemasse põlvkonda, jälgiti mingit mudelit. Nooremas peres oli pidulikkust vähem, kuid vajadus raskustest hoolimata pidada seda palvust oli olemas. Nad ei pidanud sügispalvust ainult sellepärast, et meie olime kohal. Nad teevad seda igal aastal.

\section{Söömine}

Söömine on rituaali lõppfaas, rituaalne tegevus, mis ühendab kõiki osalejaid. Siiamaani on putru õnnistanud ainult peremees, putru süües saavad kõik kohalviibijaid rituaalist osa ja palvega taotletud õnnistus laieneb ka neile. Puudujatele jäetakse ilmtingimata osa pudrust, et nad oleksid teistega vaimses ühenduses.

Peab tähele panema, et meid kutsuti kohe lauda. Olin küllaltki ettevaatlik, sest Varkled-Bodjas hoiatati meid samasuguses situatsioonis, et alguses peavad sugulased istuma omavahel, meie saame nendega liituda alles hiljem. ${ }^{11}$ Siin kinnitati korduvalt, et neil sellist kommet pole. Ma ei saa muidugi teada, kas seda öeldi viisakusest, aga üllatus, mida ma lugesin oma võõrustajate nägudelt, tundub tõestavat, et tegelikult nii ongi.

Lauad olid rikkalikult kaetud. Lisaks pudrule olid kohustuslike roogadena esindatud perenaise küpsetised: taban' ehk pärmipannkoogid, šangi'd (lahtised kartulipirukad), omaküpsetatud sai. Siis veel hoidised (tomatid, kapsad, seened, kurgid),

[11] Mulle kui võõrale poleks seda iial öeldud. Nikolai Anisimov aga on ühelt poolt ka ise udmurt, teisalt aga lähedane sõber. Seda öeldi talle otsekui häbenedes ja täpsustati, et vanasti ei lubatudki võõraid lauda. Arvatavasti ei pidanud nad silmas teadlasi, vaid teisi, sugulaste sekka mitte kuuluvaid inimesi. Vahel lähevad oma reeglid ja külalislahkus vastuollu. 


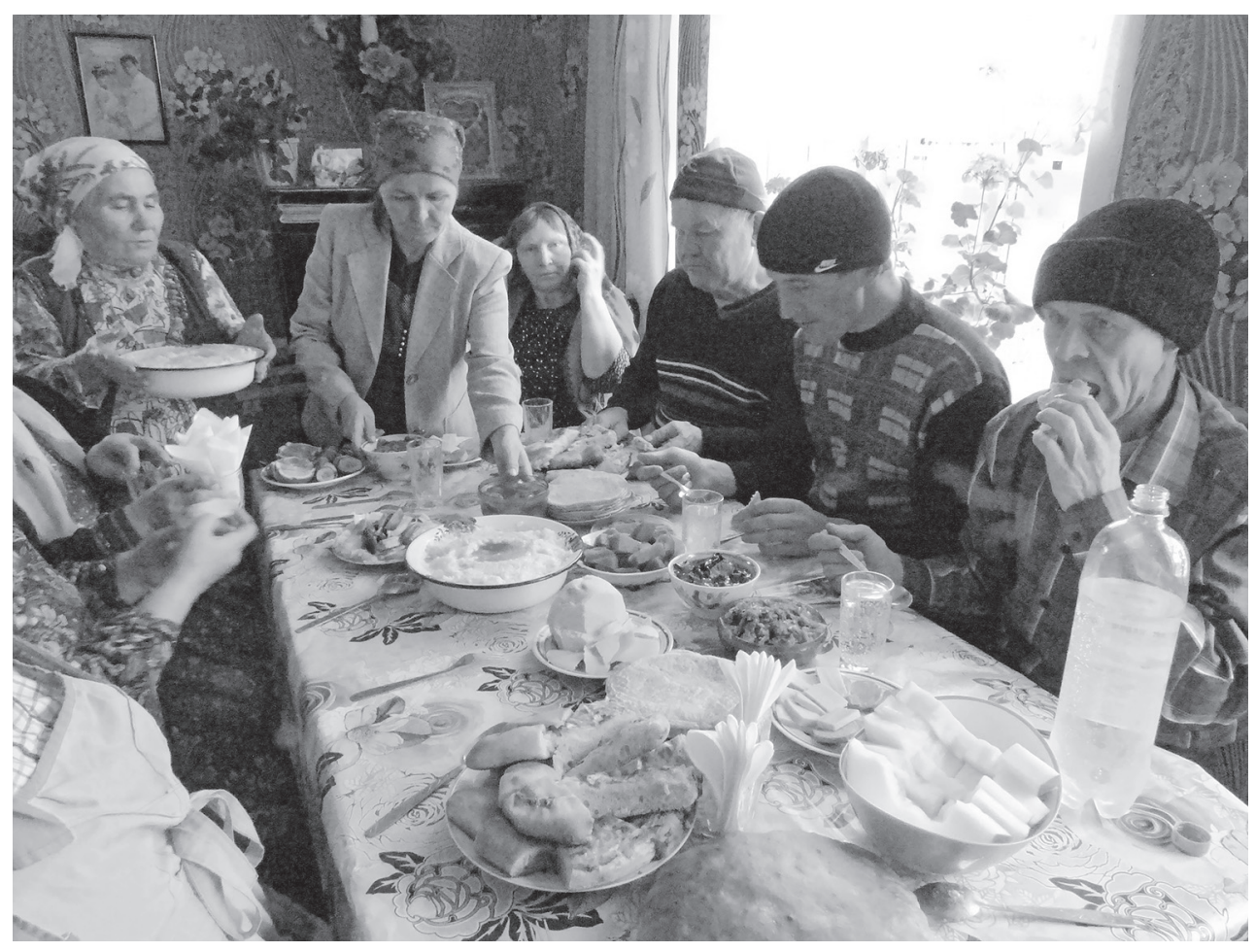

Garifanovite majapidamine.

Laudkond. Foto: Eva Toulouze 2017

keedetud kaalikad, koduvõi. Garifanovite ja Nurtdinovite peres olid lauad üsna sarnased. Nurtdinovite pool leidus lisaks värskeid tomateid, keedupeete ning haneliha, mille puljongiga oligi puder keedetud. Perenaised lisasid aeg-ajalt pudruauku sulatatud võid või siis taimeõli (Nurtdinovite peres). Garifanovite juures käis jutt sügisrituaalidest. Märgiti, et sügismälestamine (сӥзьыл кисьтон või ӟуон) on igal pool paremini säilinud. Nurtdinovite laudkond oli üsna vaikne. Lapsed sõid rahulikult koos täiskasvanutega.

Pererahvas oli enamasti püsti. Peremehel ja perenaisel ei olnudki laua taga kohta ette nähtud. Perenaised kontrollisid, et kõik oleks kogu aeg laua peal korras. Farhulla Garifanov vahel ikka istus ka, Saljahudtin Nurtdinov jäi aga kogu aeg püsti. Söögiajaks oli Farhulla oma rüü seljast võtnud, kuid kübar oli tal endiselt peas. Saljahudtin jättis rätiku ümber vöö ja tübeteika lõpuni pähe. Lõpuks istus ka Hafiza oma mehe Farhulla kõrvale ühte lauaotsa. Garifanovite juures istusid mehed perenaisest paremat kätt (see võis olla lihtsalt juhus). Nurtdinovite juures istusid mehed ja naised segamini. Samigulovite juures istusid kogu aeg kõik.

Saljahudtin Nurtdinov oli lõbus ja pakkus laua taga istuvatele külalistele oma alkoholi. Udmurdi aladel on kombeks, et iga perenaine valmistab kodus alkoholi, mida vene keeles nimetakse kumõška (kangusega umbes 20-60 kraadi, valmistustehnikad varieeruvad). Seda kasutatakse rituaalse joogina. Poeviin tuuakse külades 




Garifanovite majapidamine, Farhulla Garifanov ja artikli autor.

Foto: Irina Samigulova 2017

ainult siis lauale, kui oma samakat millegipärast ei ole. Saljahudtin jagas pitse igaühele ja naine valas neid teekannust täis. Põhimõtteliselt peab viina valamine nagu muugi serveerimine toimuma päripäeva, välja arvatud surnute mälestamiseks võetud söök-jook. Nurtdinovite pool osutus see võimatuks, ilmselt laua asukoha tõttu. Kui klaasikesed täis, ulatas peremees ka naisele pitsi ja kõik jõid. Teist korda täitis pitse peremees ise.

Garifanovite pool koristasid naised laua ära. Ülejäänud istusid sel ajal diivanitel juttu ajades. Seejärel joodi teed. Lauale toodi puuvilju, samovar, küpsetisi, mett, moosi, taldrik vorsti ja juustuga. Peremees jagas samakat. Esmalt jõi ta ise koos naisega, siis pakkus ringi teistele. Peremees avaldas survet, et üks pits joodaks põhjani. Selleks ajaks oli noorim tüdruk, umbes 20-aastane, rätiku peast võtnud. Ka peremees oli kübara kõrvale pannud.

Samigulovite peres oli laud tagasihoidlikum: lisaks pudrule ja pannkookidele šangi'd ja muud pirukad koos mee ja kommidega. Poiss, kellele oli esimesena taldrikule putru tõstetud, hakkas kohe sööma, enne veel kui isa laua juurde tuli ja palvetas. Tema jaoks oli ilmselt tegu lihtsalt järjekordse söömaajaga. Isa ja ema palvetasid, viimane vähem formaalselt, aga pikemalt. Seejärel aeti juttu. Jutt käis peamiselt väikese poisi ümber, kes küsis palju Jumala kohta. Vestlus oli kakskeelne, sest laps räägib sageli spontaanselt vene keeles, kuigi ta valdab udmurdi keelt täiesti vabalt ja vahel ka vastab vanematele selles keeles. Juua oli limonaad ja morss ning alles hiljem pakkus peremees ka viina. Ilmselt pole Irina Samiguloval aega ise samagonni keeta.

Sellised on need sügispalvused, mida ma olen saanud välitöödel jälgida. Teine töögrupp salvestas veel ühe näite samast rituaalist. Selle rituaali püsivus sõltub perest ja keskkonnast. Seal, kus vanem põlvkond on elus ja aktiivne, kogunevad paljud lähisugulased. Seal, kus see põlvkond ei ole enam tegus ja elu allub juba moodsamatele mudelitele (näiteks naine töötab aktiivselt väljaspool kodu), on toimunud mõned lihtsustamised. See, et naised töötavad tänapäeval mitte ainult oma majapidamises, vaid ka väljaspool nagu mehedki, piirab nende võimalusi korraldada argipäeval nii suurejoonelisi pidustusi, nagu varem kombeks oli pidada. Aga vähemalt Tatõšlõ rajoonis on see palvus tänini täiesti elus. 


\section{Allikad}

Heikel, Axel Olai. 1884. Tjeremissien ja votjakkien luona Birskin seuduilla, mordvalaisten luona Samaran läänissä kesällä. Museoviraston Kansatieteen käsikirjoitusarkisto.

\section{Kirjandus}

Holmberg, Uno. 1914. Permalaisten uskonto. Suomensuvun uskonnot 4. Porvoo: WSOY.

Minniyakhmetova, Tatyana. 1995. Eating of Beestings as an Original Calendar Rite of the Bashkirian Udmurts. - Mare Kõiva, Kai Vassiljeva (eds.). Folk Belief Today. Tartu: Institute of the Estonian Language and Estonian Literary Museum, 331-334.

Minnijahmetova 1996 = Миннияхметова, Татьяна Гильнияхметовна. 1996. Календарные обряды закамских удмуртов: диссертациия. Автореферат. Уфа.

Minnijahmetova 2000 = Миннияхметова, Татьяна Гильнияхметовна. 2000. Календарные обряды закамских удмуртов. Ижевск: УИИЯ

Minnijahmetova 2003 = Миннияхметова, Татьяна Гильниахметова. 2003. Традиционные обряды закамских удмуртов. Структура. Семантика. Фольклор. Tartu: Tartu Ülikooli Kirjastus.

Munkácsi, Bernhard. 1952. Volksbräuche und Volksdichtung der Wotjaken. Hrsg. D. R. Fuchs. Helsinki: Suomalais-ugrilainen seura.

Sadikov 2008 = Садиков Ранус Рафикович. 2008. Традиционные религиозные верования и обрядность закамских удмуртов (история и современные тенденции развития). Уфа: Центр этнологических исследований УНЦ РАН.

Sadikov 2011 = Садиков Ранус Рафикович. 2011. Религиозные верования и обрядность закамских удмуртов (сохранение и преемственность традиции). Уфа: Институт этнологических исследований имени Р. Г. Кузеева Уфимского научного центра PAH.

Sadikov, Minnijahmetova 2012 = Садиков, Ранус Рафикович; Миннияхметова, Татьяна Гильнияхметовна. 2012. Зарубежные исследователи этнографии, фольклора и языка закамских удмуртов: историографический очерк. - Ежегодник финно-угорских исследований 4. Ижевск: Удмуртский университет, 49-62.

Toulouze, Eva. 2014. La langue oudmourte dans la diaspora orientale : étude de cas. - Études finno-ougriennes, 45 | 2013. Les langues finno-ougriennes aujourd'hui II. http://journals. openedition.org/efo/1872 ; DOI : 10.4000/efo.1872 (viimati külastatud 17.01.2018).

Toulouze, Eva. 2016. Some Ideas about Continuity and Revitalization in the Udmurt Spring Rituals in Bashkortostan. - Праздники и обряды в Урало-Поволжье: традиции и новации в современной культуре. Самара: СГСПУ, 17-21.

Toulouze, Eva. 2017. La durabilité de l'oudmourte en république d'Oudmourtie et dans la diaspora oudmourte: une réflexion comparative. - Anthropologica. Vol. 59, No. 1. Toronto, 60-73.

Toulouze Eva, Anisimov Nikolai. 2018. "The Year Replaces the Year." Udmurt Spring Ceremonies among the Non-Christian Udmurt: An Ethnographic Analysis of Contemporary Ritual Life (on Materials from Varkled-Böd'ya Village). - Journal of Ethnology and Folkloristics. Vol. 12, No. 1 Tartu, 59-94.

Toulouze Eva, Sadikov Ranus, Niglas Liivo, Vallikivi Laur, Anisimov Nikolai. 2018. Continuity and revitalisation in sacrificial rituals by the Eastern Udmurt. Part 1 . The collective 
sacrificial rituals by the Bashkortostan Udmurt: Rooted in tradition. - Folklore. Electronic journal of folklore 72, 203-217.

Vladõkin 1994 = Владыкин Владимир Емельянович. 1994. Религиозно-мифологическая картина мира удмуртов. Ижевск: Удмуртия.

Wichmann, Yrjö. 1893. Wotjakische Sprachproben 1. Lieder, Gebete und Zauberspruche. Helsingfors.

Wichmann, Yrjö; Wichmann, Julie. 1987. Matkamuistiinpanoja. Yrjö ja Julie Wichmannin kirjeitä ja päiväkirjamerkintöjä tutkimusmatkoilta 1891-1906. Toim Irene Wichmann. Helsinki: Suomalais-ugrilainen seura.

Eva Toulouze (Dr. Hab) on Pariisis asuva Ida keelte ja kultuuride instituudi (INALCO) soome-ugri uuringute professor ning teadur Tartu Ülikooli etnoloogia osakonnas. Tema peamine huviala on Venemaa soome-ugri rahvaste kultuurid, eelkõige udmurtide traditsiooniline usund ja maailmavaade. Tema uurimused põhinevad valdavalt välitöödel kogutud materjalil.

\section{Summary: Eastern Udmurt autumn rituals: An ethnographic description based on fieldwork}

\section{Eva Toulouze}

There is a good amount of literature about Eastern Udmurt religious practice, particularly under its collective form of village rituals, as the Eastern Udmurt have retained much of their ethnic religion: their ancestors left their villages in the core Udmurt territory, now Udmurtia, as they wanted to go on living according to their customs, threatened by forceful Evangelisation. While many spectacular features such as the village ceremonies have drawn scholarly attention since the 19th century, the Eastern Udmurt religious practice encompasses also more modest rituals at the family level, as for example commemorations of the dead, Spring and Autumn ceremonies. Literature about the latter is quite reduced, as is it merely mentioned both in older and more recent works. This article is based on the author's fieldwork in 2017 and presents the ceremonies in three different families living in different villages of the Tatyshly district of Bashkortostan. It allows us to compare them and to understand the core of the ritual: it is implemented in the family circle, with the participation of a close range of kin, and encompasses both porridge eating and praying. It can at least give an idea of the living practice of this ritual in today's Eastern Udmurt villages. This depends widely on the age of the main organisers, on their occupations: older retired people will organise more traditional rituals than younger, employed Udmurts. Further research will ascertain how much of this tradition is still alive in other districts and in other places. 
Резюме: Осеннее моление закамских удмуртов: этнографическое описание ритуала на основе полевых исследований

\section{Эва Тулуз}

Существует достаточно много литературы о религиозных практиках закамских удмуртов (особенно о совместных молениях разных деревень), ибо восточные удмурты большей частью сохранили свои старые народные верования. Их предки покинули свою историческую родину, расположенную в современной Удмуртии, именно под страхом насильственного обращения в христианство, так как хотели жить согласно старым традициям. Совместные деревенские моления уже с XIX века привлекали внимание ученых, но в религиозную обрядность закамских удмуртов входят также ритуалы, проводимые в кругу семьи, такие как поминовение умерших, весеннее и осеннее моления. Об этих ритуалах достаточно мало литературы, и она ограничивается в основном краткими упоминаниями о них. Статья, основанная на проведенных автором в 2017 году полевых исследованиях, предлагает обзор осеннего моления в трех семьях, живущих в трех деревнях Татышлинского района Республики Башкортостан, и дает возможность сравнить и лучше понять сущность ритуала. Осеннее моление проводится в узком кругу близких родственников и закдючается, в основном, в поедании каши и молении. В посещенных деревнях традиция осеннего моления до сих пор еще жива. При проведении ритуала многое зависит от возраста и занятости его организаторов. Пенсионеры могут уделить организации ритуала больше времени и энергии, чем молодые, работающие удмурты. Дальнейшие исследования должны показать, насколько этот ритуал сохранился в других районах. 